\title{
Migrant Voting: Here, There, in Both Countries, or Nowhere
}

\author{
Victoria Finn ${ }^{1}$ \\ Universidad Diego Portales \\ Leiden University
}

This is a pre-print version of the peer-reviewed article in Citizenship Studies. The material cannot be used for any other purpose without further permission of the publisher and is for private use only. It should be cited as:

Finn, Victoria (2020) Migrant Voting: Here, There, in Both Countries, or Nowhere. Citizenship Studies. doi.org/10.1080/13621025.2020.1745154

\begin{abstract}
Moving past the literature on states granting migrant voting rights, in this article I focus on individuals exercising these rights in order to question the connections between (non)citizenship, political membership, and participation in contemporary societies. With over 120 countries worldwide having enfranchised migrants in some form, the binary of 'here' and 'there' is insufficient to categorize and study migrant political engagement. This article contains a new typology to classify the four options of migrant voting: immigrant (only in the destination country), emigrant (only in the origin country), dual transnational (in both), and abstention (in neither). While emigrant voting requires citizenship, immigrant noncitizen voting does not, so active noncitizen voting weakens the defining dimensions of citizenship as a concept. As a first application, I analyze differences between individuals pertaining to each of the four types, based on a 2017 survey of 680 migrants in Chile since this country grants extensive migrant suffrage rights.
\end{abstract}

\footnotetext{
${ }^{1}$ OrcID: 0000-0001-6379-3720. I would love to hear from you! Contact me with questions or comments at VickiJFinn@gmail.com.
} 
As opposed to the globalists who see immigrants living in two worlds and the nationalists insisting that these same home country connections be cut, I will show that the immigrants are instead between here and there.

(Waldinger 2015, 20)

\section{Introduction}

Universal suffrage is a cornerstone of democracy since it allows individuals in the political community to convey their preferences through participation (Dahl 1971). Disenfranchised individuals are disadvantaged to protect their interests, yet political systems continue to restrict suffrage rights (Beckman 2006, 153). ${ }^{2}$ Inclusivity can be bureaucratically cumbersome since migrant enfranchisement requires enacting, regulating, and applying voting rights (Palop-García and Pedroza 2018). More than 120 current regimes have completed some procedural steps for emigrant suffrage while about 45 grant immigrant suffrage at the local, regional, and/or national level, with universal application for all or restricted application for some (Caramani and Grotz 2015; Arrighi and Bauböck 2017; Ferris et al. 2019; IDEA 2019).

With the spread of enfranchisement, more migrant voters can convey their preferences to the origin country as a non-resident citizen living abroad and to the destination country as a dual citizen or noncitizen resident. ${ }^{3}$ Once meeting requirements, such as age, citizenship remains a sufficient

\footnotetext{
${ }^{2}$ Furthermore, Beckman $(2008,29,31,33,36)$ clarifies that restrictions are the 'usual exclusions' of felons, intellectually disabled, children, and resident immigrants, non-resident emigrants; excluding any group makes suffrage less universal, even if normatively there are reasons to 'justify' this exclusion. ${ }^{3}$ Using noncitizen and noncitizenship without a hyphen is one step in the direction of conceptualizing noncitizenship without relying on citizenship as a foundational concept (see Tonkiss and Bloom 2015).
} 
condition to gain voting rights; however, it is no longer a necessary condition: mobile individuals have more rights-based political membership in the demos, regardless of naturalization decisions. Moving forward from states adding individuals to the electorate, I ask, which migrants choose to vote or abstain, and where?

As the epigraph highlights, international migrants live in a connected world between 'here' and 'there'. Individuals living 'here' are immigrants who are noncitizen residents (foreigners or aliens) or dual citizens in the destination country, whereas 'there' refers to the origin country for emigrants abroad, also called non-resident citizens. The here-and-there binary is insufficient to classify political engagement since the option is no longer only to vote or abstain; it is to vote or abstain in the origin country and to vote or abstain in the destination country. This creates not two, but four distinct types of migrant voting.

I introduce a typology using migrant voting as a dependent variable comprising four categories: 1) immigrant voting, meaning individuals participate only in the destination country; 2) emigrant voting, indicating individuals participate only from abroad for the origin country; 3) dual transnational voting, corresponding to participating in both countries; and 4) abstention, or choosing not to vote in either country despite having suffrage rights.

The main contribution is a typology that exhaustively classifies migrant voting and serves as a framework for analyzing which migrants vote or abstain, and where. As a first application, I examine part of a growing group of migrant voters in Chile. This country is a leader in universal adult suffrage since it offers unrestricted national-level voting to both noncitizen residents as well as citizens abroad. Most immigrants in Chile do not naturalize and are primarily South Americans (CASEN 2015; DEM 2015). This means that foreign residents have access to voting rights as noncitizen residents and as a non-resident citizen for the origin country (GLOBALCIT 2018). After a five-year residence, 
immigrants face four choices for political participation: only here, only there, in both countries, or nowhere.

In the following, I explain how the present analysis fills gaps in the academic debate on political (re)socialization and participation, followed by the hypotheses. Thereafter, I introduce the migrant voting typology; its four types incite a discussion on noncitizenship as a separate concept from citizenship. Moving away from findings based on South-North migration taking citizenship acquisition as normal and beneficial, analyzing Latin American voters residing in Chile offers distinct insights regarding migrants as political insiders with low incentives to naturalize. ${ }^{4} \mathrm{I}$ justify the case and explain the survey data and method before discussing empirical results using the typology as a framework.

\section{Migrant Political (Re)socialization and Participation}

Within migrant voting analyses, some studies explain who have voting rights or why states have granted these rights (e.g., Earnest 2015; Escobar 2015; Arrighi and Bauböck 2017; Pedroza 2019). Many focus on individuals according to origin country, such as Colombians in Europe (Guarnizo, Chaudhary, and Sørensen 2017) or Ecuadorians abroad (Ramírez and Umpierrez de Reguero 2019). Beyond Canada, the European Union (EU), and the United States (US), migrant voting and citizenship literature stretches into the Middle East and North Africa (Brand 2006), Latin America (Escobar 2015; Pedroza, Palop-García, and Hoffmann 2016), the Caribbean (Belton 2019), as well as Japan (Kashiwazaki 2013), New Zealand (Barker and McMillan 2017), and South Korea (Mosler and Pedroza 2016). More scholars analyze non-resident citizen voting at the local rather than national level. Fewer

\footnotetext{
${ }^{4}$ Similarly, citizens from a European Union (EU) member state living in another EU country may also have few incentives to naturalize since they have free mobility and local-level political rights; however, this scenario is inapplicable to third-country nationals in the EU or in multilevel elections.
} 
focus solely on noncitizen resident voting, either in large-N studies (e.g., Earnest 2015) or small-N and case studies (McMillan 2015; Belton 2019; see Ferris et al. 2019). Fewer still combine the two types of voting (Escobar 2015; Waldinger 2015; Barker and McMillan 2017; Chaudhary 2018), even though each migrant is simultaneously an immigrant and emigrant, as Pedroza and Palop-García (2017) have highlighted. However, migrant voters may have different political rights in the two countries.

To contribute to this literature, I focus on the four (non)citizen migrant voting types in national-level elections in two countries. Migrant voting in Chile has largely remained unexplored, perhaps since the country did not grant emigrant suffrage rights until 2017 and the overall immigrant population had been below 1\% even in the 1990s (INE 2017). However, Chile granted universal national-level voting rights to immigrants in the Constitution of 1980 (Article 14) and since 2012 has automatically granted these rights to immigrants after five years of residence (Law N.20.568, Article 6, 2012). In 2017, this group represented about $\%$ of the electorate (SERVEL 2017). Electoral studies scholars have also analyzed how municipal-level immigrant density affects overall turnout of migrant and native-born voters (Herrera and Navia, unpublished) but disregards the origin country and the citizenship aspect of migrant voting.

The level and type of participation involves the individual's relation with the origin country, its government, and family and friends still there. For instance, emigrants may join political campaigns, be active in hometown civic associations, or donate money or time to civic projects in the origin country (Guarnizo, Portes, and Haller 2003, 1223). Along with typical voting factors such as age, education, and interest in politics, both emigrants and immigrants make decisions on how and in which ways to politically participate based on the ease of involvement, residence, intention to stay, and geographical distance between the two countries (see, e.g., Peltoniemi 2018). The process of 
forming transnational ties is critical in this process (Boccagni and Ramírez 2013) since it affects the ways in which migrants are politically active.

Being in two political communities allows international migrants the chance to develop multiple political identities through learning in two countries, in the transnational space, and within the migratory system (Glick Schiller, Basch, and Szanton Blanc 1992; Guarnizo, Portes, and Haller 2003; Østergaard-Nielsen 2003; Waldinger 2008, 2015; Erdal and Oeppen 2013; Paul 2013; Chaudhary 2018). In these socialization spaces, international migrants interact with individual and institutional agencies (Østergaard-Nielsen 2003; Paul 2013). Socialization means the "learning of social patterns corresponding to... societal positions as mediated through various agencies of society" (Hyman 1959, 25). Political learning begins in the formative years and affects political participation but is not deterministic because learning continues throughout life (Hyman 1959; Niemi and Hepburn, 1995; White et al. 2008). Since "there is no single pathway to political learning" (White et al. 2008, 277), learning outcomes shape political attitudes and values in different ways, resulting in varying electoral behavior. Combining learning with gaining political rights, migrants face new scenarios for political participation in more than one place.

Political learning continues throughout life, but for migrants international migration initiates their political resocialization process. ${ }^{5}$ Building from the literature (e.g., Hyman 1959; Bender 1967;

\footnotetext{
${ }^{5}$ International migrants undergo a political resocialization process in the destination country postmigration, after having experienced the political socialization process in the origin country premigration. If the migrant is a child who has never gone through this process, then it would be their initial political socialization process. Addressing the assumption that all individuals undergo political socialization (and all international migrants, resocialization), is that everyone living within a society has interactions and experiences with those surrounding them, learns from them, and internalizes various
} 
White et al. 2008; Paul 2013; Wasburn and Adkins Covert 2017), I use the following definition: political resocialization is a cognitive learning process during which individuals maintain or adjust political attitudes, values, and behavior based on individual and institutional agents within a new context. I expect that over time, immigrants' multifaceted political participation in the destination country will increase, if not only for the fact that it was zero prior to migration. Contrarily, emigrants' post-migration participation in the origin country may increase, remain the same, or decrease.

Addressing two of these three possibilities, Chaudhary's (2018) innovative analysis concerned with integration - based on 12 immigrant groups in seven European cities - finds evidence for migrant voting in the origin country to either increase or decrease over time. An increase (the 'complementary perspective') relates to Tsuda's $(2012,635,638)$ 'positive reinforcement' of engagement between the two places or to 'co-existence' when migrant participation augments in both countries but voting in one does not necessarily influence voting in the other. A decrease (Chaudhary's 'resocialization perspective') indicates Tsuda's (2012) 'zero-sum relationship' between engagement in the two places, meaning identity and loyalty are linked to only one country: a migrant forfeits prior ties to 'make room for' connections to the destination country (Guarnizo, Chaudhary, and Sørensen 2017, 4).

Part of political integration in much of the Global North is citizenship acquisition, while this does not hold the same meaning and benefits in other contexts, for instance for South American immigrants in Chile who possess extensive social, economic, and political rights in two countries and choose not to naturalize. Using Joppke's (2007) citizenship status versus rights, although the destination country has 'liberalized' access to citizenship, it is not the only path to gaining the same suffrage rights. While naturalization is the 'traditional' way to obtain the franchise, noncitizen resident

attitudes, beliefs, and values. Political learning will affect people in different ways and to varying degrees, but nonetheless occurs for all individuals. 
voting is another (Pedroza 2019, 9). An additional result during the resocialization process is that migrants maintain enough connections to keep the same probability of origin country voting: in other words, it does not increase or decrease.

While I do not expect all migrants to vote, casting a ballot shows that rights are more than symbolic, since migrants face no additional barriers to exercise suffrage rights, if they wish. The questions are then when, where, and who participates. The aforementioned perspectives include the extent to which migrants' length of residential tenure in the destination (as an independent variable $X)$ affects the level of political engagement in the origin country (the dependent variable $Y$ ) since a change in $X$ causes a change in $Y$. Between, Chaudhary inserts the mechanism $(M)$ as political and civic incorporation in the destination country. Instead, I frame the dynamic political resocialization process as the mechanism $(M)$. Migrant voters are capable of maintaining or adjusting political attitudes, values, and behavior in more than one location. Migrants 'pivot' between being more politically involved in one country or the other at various points (Tsuda 2012), choosing among the four viable possibilities of migrant voting.

\section{Hypotheses}

Migrant voters exercising political rights across borders play a role in election outcomes in more than one country (White et al. 2008; Tsuda 2012; Paul 2013; Gamlen 2015; McMillan 2015; Chaudhary 2018), thus it is imperative to understand which migrants are expressing their preferences in which political systems. Before voting, the post-migration political learning curve entails gaining information about democratic institutions and government branches, electoral laws, and new political parties. Migrants learn through direct and indirect interactions with other individuals, institutions, and (non-)state actors. Migrants must also know if and when they gain voting rights. In South America, I 
expect emigrant voters residing in Chile to know they can continue voting from abroad. ${ }^{6}$ Contrarily, national-level noncitizen resident voting is less common-but yet Chile automatically registers immigrants into the electorate after a five-year residence-therefore I expect many immigrants are unaware of this right:

H1: Immigrant voters who know they have suffrage rights are more likely to participate in immigrant or dual transnational voting, as compared to those who are unaware of these rights.

The result of socialization affects political engagement in the origin country, with the potential to bring these political experiences with them across borders; post-migration resocialization has the potential to affect the individual's behavior in more than one territory. One inherent characteristic that can cross borders is an individual's interest in politics. I expect that those who are more interested will engage in both the origin and destination countries:

H2: Migrant voters reporting a higher interest in politics are more likely to participate in dual transnational voting.

Ties with states, or with those residing there, can also affect political participation. Ties include information flows and connectedness to family or assets, or to the nation-state or nationality (Boccagni and Ramírez 2013). Given connections in two places, migrant voters 'balance' two political communities, from which they select how, and in which ways, to be politically engaged in each location

\footnotetext{
${ }^{6}$ Compulsory, or mandatory, voting systems require individuals to vote and may have automatic or optional registration. These have been a common practice throughout South America. Instead of abstaining, voters may cast blank (null) ballots. Contrarily, voluntary, or facultative voting systems allow individuals the choice to vote or abstain.
} 
(Erdal and Oeppen 2013). I expect the intention to stay in the destination country to affect behavior since long-term plans relate to potential future benefits:

H3: Migrant voters reporting a longer intention to stay in the destination country are more likely to participate in immigrant or dual transnational voting.

Related, migrants' connections to and experiences in two or more locations will change over time, affecting voting turnout decisions in the origin and destination countries. The political resocialization process results in migrants adjusting some of their political attitudes, values, and behavior. Facilitating this process is communication: the more of the destination country's language a migrant speaks, the faster one can gain information. Most intraregional migrants in South America speak Spanish (or Portuguese); however, communication rather than fluency is key, due to the wide variations in the language. High communication will augment the likelihood of being able to political engage in the destination country:

H4: Migrant voters reporting high linguistic communication are more likely to participate in immigrant or dual transnational voting.

\section{The (Non)Citizen Migrant Voting Typology}

Combining emigrant (non-resident citizen) with immigrant (noncitizen resident) voting, this typology can include local-, regional-, and/or national-level rights. 
Victoria Finn

Pre-Print of Migrant Voting in Citizenship Studies

Figure 1 Migrant Voting Typology

\begin{tabular}{|c|c|c|c|}
\hline \multicolumn{3}{|c|}{ Migrant voting } \\
\hline \multicolumn{2}{|c|}{} & \multicolumn{2}{|c|}{ Votes in origin country } \\
\cline { 2 - 4 } & & Yes & No \\
\hline \multirow{2}{*}{$\begin{array}{c}\text { Votes in } \\
\text { destination } \\
\text { country }\end{array}$} & Yes & $\begin{array}{c}\text { Dual transnational } \\
\text { voting }\end{array}$ & $\begin{array}{c}\text { Immigrant } \\
\text { (noncitizen resident) } \\
\text { voting }\end{array}$ \\
\cline { 2 - 4 } & No & $\begin{array}{c}\text { Emigrant } \\
\text { (non-resident citizen) } \\
\text { voting }\end{array}$ & Abstention \\
\hline
\end{tabular}

Source: Author's typology.

Notes: The term 'immigrant' refers to foreign-born noncitizen residents and dual citizens, whereas 'emigrant' refers to non-resident citizens, independently of whether they are only citizens of the origin country or also citizens of the destination country.

The static typology becomes dynamic when measuring and explaining individual or group movements between quadrants. One can track individual movements between quadrants through the political resocialization process. For instance, a voter may be interested in politics but chooses to abstain if she considers the origin country non-democratic. Post-migration, she may partake in immigrant voting in the destination country. Stasis is also possible: one who abstains in the origin country may continue to abstain also in the destination country, despite having voting rights. Abstention exemplifies mutually negative reinforcement of transnational engagement (Tsuda 2012, 635). Others may move several times and in multiple directions, indicating nonlinearity. However, when simultaneous participation in two countries is positively reinforcing (Tsuda 2012, 644), once a 
migrant is in the dual transnational voting quadrant, it is easier to remain there for the long term. While mobility is expected, the typology is non-normative since none of the quadrants represents an ideal 'final' location.

The three types of active migrant voters are immigrant, emigrant, and dual transnational. The last category is distinct since dual transnational voters participate in elections in the origin and destination countries, whereas both emigrant and immigrant voting occur in only the origin or destination country, respectively (see Figure 2). As Tsuda (2012, 633) highlights, it is the simultaneity of dual engagement in at least two countries that distinguishes transnationalism from nationalism.

Figure 2 The Relation Between the Four Types of Migrant Voting

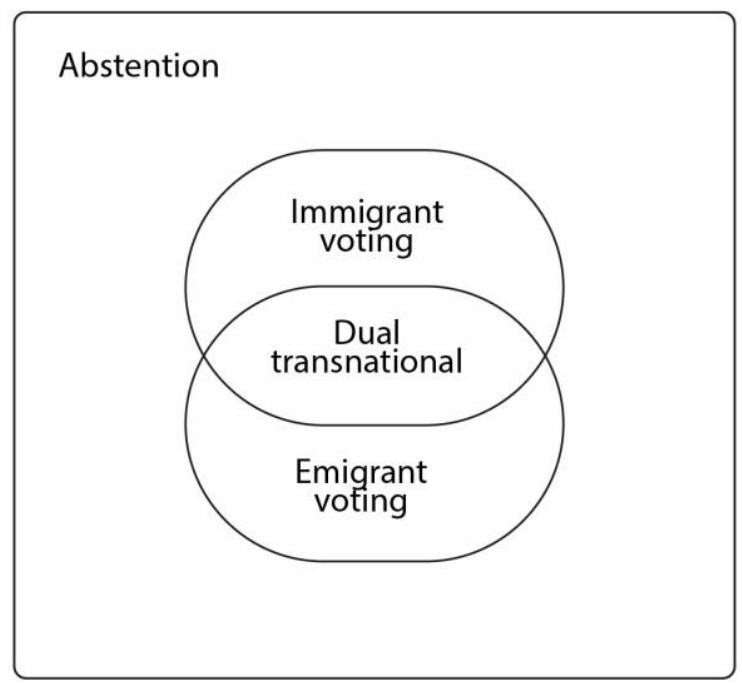

Source: Author's construction.

Political practices 'that transcend the borders of independent states are transnational if they involve simultaneous overlapping affiliations of persons to geographically separate polities'; 'affiliations' refer to memberships, rights, and practices in two locations (Bauböck 2003, 705, emphasis in original). 'Transmigrants develop and maintain multiple relations - familial, economic, social, organizational, religious, and political that span borders' (Glick Schiller, Basch, and Szanton Blanc 
1992, 1). Migrants who vote in two sovereign territories are dual transnational voters since they vote from abroad in the origin country and simultaneously vote in the destination country.

\section{(Non)Citizens' Political Rights and Membership}

Considering Bauböck’s (2006) conceptual dimensions of national citizenship - legal status, rights, and political participation - when noncitizen residents vote, noncitizens mirror citizens. This blurs the conceptual difference between (non)citizenship. While political rights had traditionally been the key defining factor of full citizenship (Marshall 1964), more countries are including foreigners in the demos. Foreign-born noncitizens still lack widespread full political rights, for example to be elected as a high-ranking official. Yet countries have started to unbundle citizenship-related rights with the franchise. This unbundling does not call for including noncitizens into the concept of citizenship, but rather for conceptualizing noncitizenship separately, as Tonkiss and Bloom (2015) in a special issue in this very journal have suggested. They challenge citizenship as the sole foundational concept while analyzing situations in which noncitizens claim and access political rights. When a noncitizen also has legal status to reside in the country, voting rights, and chooses to participate politically in the destination country, it weakens the defining dimensions that describe national citizenship as a concept.

Citizens who meet basic requirements continue to be members who can exercise political rights (Caramani and Grotz 2015), following 'the idea that political power is for members only, and the most fundamental indication of membership is citizenship' (Beckman 2006, 155). Yet, citizenship has moved 'beyond nationality' since citizenship identities can be 'universalistic' and no longer necessarily define membership (Beckman 2006; Joppke 2007, 37; Pedroza 2019). Postenfranchisement, migrants who exercise suffrage show that rights are more than political symbolism. Casting a ballot mixes the 'domains' of rights-based with membership-based transnationalism (Fox 2005, 192); noncitizen migrant voting demonstrates another way to be an active member. In Latin 
America, citizenship as participation in the political community (rights in exchange for duties) constitutionally differs from nationality, which is national belonging or legal membership (Escobar 2015, 928; Pedroza and Palop-García 2017). Although one may feel a sense of citizenship through active participation, given noncitizens are also voting, 'citizenship' is no longer appropriate to describe this context.

\section{Using the Typology: Data and Method of Analysis}

Using the typology as a framework, the rest of the present analysis contains an empirical exercise with the purpose of examining which migrants choose to exercise voting rights, and where. When states extend suffrage to noncitizen residents who also have non-resident citizen voting rights, it is possible to find dual transnational voting, which is where I begin my case selection. Regardless of nationality, national-level suffrage is a reality for immigrants in five countries: Chile, Ecuador, Malawi, New Zealand, and Uruguay. I discard New Zealand due to existent thorough analyses (McMillan 2015; Barker and McMillan 2017) and exclude Malawi because of its very low and decreasing in-country immigrant stock, with foreign-born residents totaling 1.3\% of the total population (UN DESA 2017, 25). Immigrants can obtain national-level voting rights in Ecuador (after a five-year residency period), Chile (after five years), and Uruguay (15 years). ${ }^{7}$ Foreigners in these countries primarily originate from

\footnotetext{
${ }^{7}$ Margheritis (2015, 7-8) reports that Uruguay is the most restrictive not only for its higher required residency, but it also further limits eligibility, outlined in Article 78 of the National Constitution. The Electoral Court issues voter registration, allowing noncitizen residents to vote, but only those who can provide documentation proving the following: exhibit good behavior (i.e., no criminal record), own property or capital in Uruguay, have an occupation or profession, have formed a family in Uruguay, and have been a resident for the last 15 years.
} 
another South American country, almost all of which extend emigrant voting rights - the relevant exception being Uruguay (GLOBALCIT 2018). Analyzing migrants in South America fills a geographic gap in noncitizenship studies (Tonkiss and Bloom 2015). While analyzing national-level voting, this region holds the likely cases in which to find individuals who can fall into any of the four migrant voting categories.

I analyze migrant voting in the 2017 Chilean presidential election for four reasons. First, the country is more inclusive than Uruguay since it automatically grants national-level noncitizen suffrage after five years (and grants external emigrant voting rights). Since structural barriers are low, I expect more inclusive electoral systems to have higher participation. Second, 2017 was the first presidential election in which Chileans abroad could vote, drawing attention to migrant voting in general, even though immigrants have had universal suffrage since $1980 .^{8}$ Third, the migrant stock was below $1 \%$ in the 1990 s, tripled by 2015 , and then almost doubled again by 2018 , resulting in about $5 \%$ foreignborn in the total population (INE 2017). The quick uptick since 2010 has sparked exclusive migration policy (Finn and Umpierrez de Reguero 2020) but many cohorts have become eligible to vote. Fourth, despite citizenship being accessible due to few requirements, Chile has a low naturalization rate: only 0.14\% of the foreign-born naturalized in 2015 (CASEN 2015; DEM 2015). ${ }^{9}$ This is relevant because

${ }^{8}$ See Article 14 in Chile's Constitution of 1980, as well as details in Article 60 of the Organic Constitutional Law No. 18700 on Voting and Scrutiny. Local voting rights for select noncitizen residents in Chile date as far back as 1925 (Echeverría 2015, 6-7).

${ }^{9}$ National-level surveys from 2015 show that $13.1 \%$ of the foreign-born in Chile hold dual citizenship of Chile and another country, although not necessarily the origin country; $8.2 \%$ of these foreign-born hold solely Chilean citizenship; and 78.8\% hold solely another non-Chilean citizenship. Migrants may 
noncitizens who choose to vote do so with little expectation of becoming a citizen. The decision to not naturalize is a valid possibility in this South American scenario since migrants already have extensive social, economic, and political rights. This clashes with the citizenship premium found in select South-North migration patterns, for example for third-country nationals moving to a more economically developed country within the EU (Peters, Schmeets, and Vink 2019).

\section{Data Collection and Method}

Before Chile's 2017 presidential election, I surveyed immigrants residing there through an original online questionnaire designed in Qualtrics and promoted via Facebook. ${ }^{10}$ As a Facebook optin survey, the sample is not random, thus the results hold internal validity only for these respondents; I do not generalize to all migrant voters. Online surveys offer quick data collection, are inexpensive, and eliminate interviewer bias (Berrens et al. 2003), as well as allowed me to obtain a large sample. Of 1,485 respondents, the sample size is 680 since this analysis includes only migrants who have voting rights.

The survey contains three sections: demographics, socioeconomic standing, and political engagement (see Supplemental Material). It was available for five days up until the polls opened on

have obtained citizenship via ius sanguinis or through historical or colonial ties with countries such as Italy, Portugal, or Spain.

${ }^{10}$ The Research Ethics Committee within the Faculty of Social Sciences and History at the Universidad Diego Portales, Santiago, Chile, had approved the survey. Additionally, I obtained informed consent from each participant; after reading information about the survey and participant anonymity, each respondent answered the question, in Spanish, 'do you accept participating in this study under the previously listed conditions?' Only those clicking 'yes' could proceed to the survey. 
election day November 19, 2017 and another five days before the second round December 17, 2017. Respondents qualified by being of voting age, being foreign-born, and residing in Chile. ${ }^{11}$ The dependent variable is previous migrant voting using the four types (immigrant, emigrant, dual transnational, and abstention). On this nominal multicategorical dependent variable, I conduct a multinomial logistic regression. Since memory is imperfect, I expect some misreporting. I consider only actual past behavior as voting, not the intention to vote, whereas abstention is never having voted.

A survey bias is that respondents needed a Facebook account and to log in when the survey was open. Although a non-political photo advertised the survey, there could be selection bias since I conducted it before the election. Stating 'your voice counts' implied political voice, appealing to

${ }^{11}$ To find survey respondents, I applied a Facebook filter for foreign-born persons who entered the site from a Chilean http; this group saw an advertisement on their newsfeed. The photo displayed international flags and stated, in Spanish, 'Immigrant in Chile? Your voice counts! A brief survey.' Clicking on this redirected the individual to the Qualtrics survey. The survey was advertised and conducted only in Spanish since most immigrants are intraregional and must live five years in Chile before gaining voting rights. For those failing to meet the age or location requirements asked in the first questions, the survey closed. Of the survey respondents, I eliminated: a) those who had answered less than $70 \%$ of the survey (deleting 932 surveys from November and 707 from December); b) those who completed the survey in less than three minutes (90 the first round and 46 the second) since this is an inadequate amount of time to have properly comprehended the questions; and c) the very few 'repeat' surveys that shared an http address and had copy and pasted responses to the open-ended questions. For the purpose of this article, I also eliminated anyone who had not yet gained voting rights in Chile, resulting in a sample size of 680. 
Victoria Finn

Pre-Print of Migrant Voting in Citizenship Studies

respondents interested in politics, which could have affected the decision to vote as well as the decision to answer the survey. Furthermore, while it captured migrants' electoral behavior in the past and present in two countries, a design flaw creates a limitation to the study: the question about past voting in the origin country failed to specify whether this was before or after migration. Although this disrupts proper categorization for emigrant and dual transnational voting, it is not detrimental to achieving this article's objectives, as discussed in the sample results section.

Regarding the operationalization of the four independent variables, the responses for knowledge of voting rights are: yes, no, or I don't know. The second two are to gauge how many migrants in the sample - who have immigrant voting rights due to a five-year residency - are unaware of this right. For interest in politics respondents could choose the standard options of very interested, somewhat interested, or uninterested. For intention to stay, respondents answered if they plan to stay up to five more years, 6-10 more years, forever, or don't know. Intention disregards how long migrants have already lived in Chile, focusing only on future plans. For linguistic communication, respondents answered that they can communicate in Spanish in Chile all the time, frequently, sometimes, or rarely. From these, I group the first two together, labelling it as 'high' and the second two as 'low' linguistic communication.

For control variables, exact age is grouped into $16-24,25-33,34-42,43-50$, or over 50 . I calculate in-country tenure by subtracting the arrival year from 2017 and then group them into 6-10, 11-20, or more than 20 years. Tenure of five years or below is inapplicable since I include only migrants who have multilevel voting rights in Chile. Condensing the completed education categories, I label them high school or lower, professional training, and university (both under- and postgraduate). Sex is woman or man, recoded from the question on gender. Based on origin country responses, I separate them into border countries (Argentina, Bolivia, and Peru) and also other Latin 
Victoria Finn

Pre-Print of Migrant Voting in Citizenship Studies

American and Caribbean countries. Elections are the first round of the primary with eight candidates in November 2017 and the second round between two candidates in December 2017.

\section{Descriptive Sample Results: A Snapshot in Time}

The sample size of 680 comprises an almost even number from each of the two presidential election rounds in November and December 2017 (see Table A1). As Doña Reveco and Sotomayor's (2017) previous exploratory work in Santiago, Chile, has also shown, a large number of foreigners $43 \%$ in this sample - lack information or have misinformation regarding their right to vote in nationallevel elections. A third of these individuals are unsure if they have suffrage rights or not, while the rest report that they do not have rights, when in fact they do. The exceptions would be if respondents had spent more than one year outside of Chile and lost continuous residence, or if they are undocumented migrants, which is possible, but unlikely given the sample's tenure and socioeconomic standing.

Lacking knowledge of voting rights is odd since a mere $10 \%$ report a lack of interest in politics; it seems natural that those interested in politics would investigate if they had the franchise. Over 90\% report an intention to stay in Chile long term for six years or more, with 330 individuals answering that they plan to stay 'forever'. While all respondents have already lived in Chile for at least five years, $38 \%$ self-report low linguistic communication; these respondents feel that they can only 'sometimes' or 'rarely' communicate clearly and coherently in Spanish in Chile. The sample includes a wide age range, with about half being between 25 and 42 years old. Respondents have high tenure: $85 \%$ have lived 6-20 years in Chile and the rest have been there for over two decades. Individuals are highly educated since a third have completed university, attaining either an undergraduate or postgraduate degree, and another third have undergone professional training. There are more women than men, about $60 \%$ and $40 \%$, respectively. Regarding origin country, $7 \%$ of respondents are from a country 
outside the region and about 93\% are from a Latin American or Caribbean country, of which about 45\% come from a bordering country (Argentina, Bolivia, or Peru).

Overall, this is a highly educated, slightly more female sample who are interested in politics; almost all originate from a Latin American or Caribbean country and half plan to stay in Chile for the rest of their lives. This data fits well with recent demographics and immigrant profiles in Chile. Long tenure and intention to stay also fit with geographic distance to border or regional countries; in most cases migrants can return to the origin country more easily and frequently, as well as hear more news on the destination country's national media coverage. Being from the region increases fluency in Spanish - although not necessarily communication - meaning the respondents can gain information about politics and elections even though they may not engage with Chileans about politics.

The sample contains individuals from each quadrant of the typology, with $80 \%$ in the emigrant voting category, followed by dual transnational voting (340 and 207 respondents, respectively; see Figure 3). Only 15\% abstained in national-level elections in both countries, meaning the survey captured a politically active sample. Importantly, Figure 3 is not to summarize or forecast migrant voting in Chile; rather, it shows a snapshot in time for this sample, demonstrating the typology's utility. 
Figure 3 Number of Respondents and Percentage of Sample, by Migrant Voting Type

\begin{tabular}{|c|c|c|c|}
\hline \multicolumn{4}{|c|}{ Migrant voting } \\
\hline & & \multicolumn{2}{|c|}{ Votes in origin country } \\
\hline & & Yes & No \\
\hline \multirow{2}{*}{$\begin{array}{l}\text { Votes in } \\
\text { destination } \\
\text { country }\end{array}$} & Yes & $\begin{array}{c}\text { Dual transnational voting } \\
207 \text { respondents } \\
30 \% \text { of the sample } \\
36 \% \text { of active voters }\end{array}$ & $\begin{array}{l}\text { Immigrant voting } \\
33 \text { respondents } \\
5 \% \text { of the sample } \\
6 \% \text { of active voters }\end{array}$ \\
\hline & No & $\begin{array}{l}\text { Emigrant voting } \\
340 \text { respondents } \\
50 \% \text { of the sample } \\
58 \% \text { of active voters }\end{array}$ & $\begin{array}{c}\text { Abstention } \\
100 \text { respondents } \\
15 \% \text { of the sample }\end{array}$ \\
\hline
\end{tabular}

Source: From the author's survey, Chile 2017.

Notes: Each type of migrant voting contains the number of respondents who correspond to the category, followed by the percentage they represent within the sample $(N=680)$. Since abstention comprises migrant non-voters, within the three active voting quadrants, I also provide the percentage of this smaller sample $(\mathrm{N}=580)$.

Dual transnational migrant voters comprise $30 \%$ of the sample, which is higher than expected. The aforementioned lack of distinction between voting in the origin country before and after migration could overestimate voters in this category. Another possibility is that these individuals' origin countries had had compulsory voting systems and thus they continue voting because they had previously created this habit (emigrant voting was mandatory only for Peruvian citizens abroad). Ignoring the $15 \%$ who choose not to exercise voting rights, active voters in the sample comprise 580 individuals. Within this group, $58 \%$ are emigrant voters, $36 \%$ dual transnational voters, and $6 \%$ are 
immigrant voters; this means that most individuals who vote in the destination country also vote in the origin country. Even if the survey question miscategorized some of these voters as dual transnational, having voted in the origin country before migration and in the destination country after migration would place these individuals in the immigrant voting category. These two categories would still comprise the same $42 \%$ of the sample.

\section{Sample Results: The Four Types of Migrant Voting}

The multinomial logistic regression columns in Table A2 comprise immigrant, emigrant, and dual transnational voting from the multicategorical dependent variable, using abstention as the reference category. Three tests confirm the robustness of the model; the most conservative (McFadden Test) explains about 30\% whereas the least modest (Nagelkerke Test) explains 54\%. These indicate that this regression explains well which migrants from this sample vote and in which location.

The first hypothesis is that those who know they have suffrage rights as an immigrant in the destination country are more likely to vote there, as compared to those who are unaware of these rights. Since many individuals lack information about immigrant suffrage rights, being ill-informed or uninformed both have highly significant inverse relations to participating as a dual transnational voter. Similarly and also significant, those who are unsure if they have these rights are less likely to be in the immigrant voting category. The second hypothesis is that migrant voters reporting a higher interest in politics are more likely to participate in dual transnational voting. Only respondents who are very interested in politics have a high and significant probability of being a dual transnational voter, being active in the two countries.

The results only partially support the third hypothesis that migrant voters reporting a longer intention to stay in the destination country are more likely to participate in immigrant or dual transnational voting. Responses of planning to stay up to another five years in Chile are indeed 
positively related to dual transnational voting; however, it is the only significant result stemming from this variable. One interpretation is that these respondents, having already lived in Chile for at least half a decade, were already politically engaged in Chile but are now engaging with the origin country since they may return in the near future. Instead of political resocialization instigating enduring electoral behavioral changes, dual engagement could come from wanting to stay in touch, or get back in touch, with the origin country to which they will return. Intentions to stay up to ten years changes to a negative, but insignificant, relation with dual transnational voting. The last hypothesis is that migrant voters reporting high linguistic communication are more likely to participate in immigrant or dual transnational voting since communication facilitates engaging in politics. The regression shows that low communication is significant only for increasing the chances of dual transnational voting. Again distinguishing between fluency and communication, respondents may vote in both places but refrain from communicating much about politics in the destination country.

The significant control variables are age, origin country, and tenure. The youngest cohort of under 25 years old is highly significant and negatively related to both emigrant and dual transnational voting. Since they have lived in the destination country at least five years, this finding greatly supports socialization explanations linked to electoral behavior. These individuals had not completed political socialization in the origin country before emigrating, so are less engaged with origin country politics.

Not being from a border country has a negative relation with voting and is significant for both emigrant and dual transnational voters. This possibly implies that respondents have a higher chance of maintaining the origin country's political identity or civic duty when the migrant is physically closer to the origin country. This parallels Chaudhary's (2018) finding that as geographic distance increases, it is less probable that a migrant voted in the origin country's last election. The present sample shows that farther distance not only lowers emigrant voting but also reduces the probability of immigrant voting. 
As tenure in the destination country increases, immigrant and dual transnational voting are positive and emigrant voting is negative - although only significant between 11 and 20 years of residence. This contrasts Chaudhary's (2018) 'complementarity perspective' (based on, e.g., Guarnizo, Portes, and Haller 2003) and better aligns with Waldinger's (2008) findings that post-migration, an emigrant decreases political engagement with the origin country. However, it is not necessarily because individuals replace previous political attitudes, values, and behavior due to new connections in the destination country in a sort of zero-sum relationship (Guarnizo, Chaudhary, and Sørensen 2017; Tsuda 2012). Electoral behavior could more slowly morph since, in the sample. this change appears only after residing more than a decade in the destination country.

\section{Conclusion}

Distinguishing 'here' from 'there', international borders demarcate boundaries of (non)citizens' political membership. States around the globe are expanding universal suffrage so individuals crossing borders transport voting rights and gain additional rights. While legally permitting more individuals to vote makes a democracy more inclusive (Beckman 2008), 'transnational voting rights per se are neither an enhancement of democracy nor a threat to its stability' (Caramani and Grotz 2015, 801). Taking a step past enfranchisement, I tackle the question of which migrants vote and where. As the present typology outlines, more migrants are facing four choices: to vote only here, only there, in both countries, or nowhere.

After the procedural steps of enfranchisement, democracy's dimension of universal suffrage has extended since the demos is more inclusive. However, granting rights is a necessary, but insufficient, condition for the outcome of migrant voting. Active members of the demos can voice demands via this traditional route; fluctuating levels of turnout do not undermine this universality. Emigrant voting in national-level elections changes political practices reserved for residents within a 
territory, in turn strengthening the link between legal status and political participation in the origin country. Contrarily, immigrant voting changes the traditional understanding of political participation exclusively reserved for citizens.

Noncitizen resident voting in national-level elections weakens the meaning of national citizenship as a concept since its dimensions of legal status, rights, and political participation, as Bauböck (2006) defines, can also describe noncitizenship. This blurring of the (non)citizen conceptual divide does not necessarily point to a decline in citizenship or its practices, since this sample showed more individuals participating in national-level elections as non-resident citizens than as noncitizen residents. Rather, it calls for renewed conceptualizations of both citizenship and noncitizenship in contemporary democracy. The concepts will lack clarity until scholars, a) find new differences between national citizens and noncitizens, or b) continue separating (non)citizens only by legal status, but not by suffrage rights or political participation.

Focusing on one type of political participation, the present article is the first to my knowledge that has offered a systematic and collectively exhaustive way to classify then analyze migrant voters. The typology allows scholars to examine changes in individual-level voting over time as relations with the origin and destination countries change. It highlights migrant voting is multicategorical with four types: immigrant, emigrant, dual transnational, and abstention. At any given time, a migrant belongs to only one category but can move back and forth between quadrants throughout the nonlinear migration trajectory.

As a first application of the typology, I conducted a Facebook-promoted survey before Chile's 2017 presidential election. The findings are based on a sample of 680 migrants who have nationallevel voting rights in two countries. I addressed four hypotheses regarding knowledge of immigrant voting rights, interest in politics, intention to stay in the destination country, and linguistic communication. Despite legally having membership in the demos, immigrants remain ill-informed or 
uninformed of suffrage rights. In this sample, this is highly significant to explain lower dual transnational participation. What indeed motives migrants to exercise suffrage rights as dual transnational voters is being very interested in politics, which is enough to vote in national-level elections in two countries. Those planning to move away from the destination country in the shortterm future are significantly likely to vote in origin-country elections, while continuing to also vote in the destination country. Communication was less significant since migrants with poor communication skills still vote in both territories.

The high rate of migrant political participation reflects lower structural barriers for active migrant voting, as compared to the US or countries in the EU. Analyzing countries without a large citizenship premium, this sample of almost entirely Latin American voters residing in a country within the same region positions migrants as political insiders who vote in more than one country, regardless of naturalization decisions. High respondent participation is not synonymous with inclusive engagement for all; this sample is highly educated and interested in politics, thus may be an elite group of likely (emigrant or dual transnational) voters. Future research would further explain why some migrants choose to exercise voting rights in one or two countries by answering the question, why are migrants located in one quadrant, and not another, within the migrant voting typology? This sample is a step toward showing Latin American countries' high inclusivity of political rights not only on paper through migrant enfranchisement, but also in practice through migrant voting.

\section{Funding}

This work was supported by the Fondo Nacional de Desarrollo Científico y Tecnológico [Regular 1161262]. 
Victoria Finn

Pre-Print of Migrant Voting in Citizenship Studies

\section{Acknowledgments}

I am indebted to Sebastián Umpierrez de Reguero for his time on the database and regression, as well as his continued support. My appreciation to Carlos Meléndez for help on the survey design and funds to conduct the survey (FONDECYT 1161262) and to José Coronado for graphic design. I thank the American Political Science Association for a travel grant to present a preliminary outline of this work at APSA 2018. For insightful comments and conversations, I thank Jean-Thomas Arrighi, Ali Chaudhary, Jay McCann, Paolo Moncagatta, Alina Ostling, Pau Palop-García, Beth Whitaker, and the GLOBALCIT Annual Conference 2018 participants.

\section{Author Biography}

Victoria Finn is a PhD Candidate in Political Science at the Universidad Diego Portales, Chile, and in Humanities at Leiden University, the Netherlands. Focusing on South America and the European Union, she researches migrant voting, citizenship, and regional migration governance.

\section{References}

Arrighi, J.-T., and R. Bauböck. 2017. “A Multilevel Puzzle: Migrants' Voting Rights in National and Local Elections.” European Journal of Political Research 56 (3): 619-639. doi.org/10.1111/1475$\underline{6765.12176 .}$

Barker, F., and K. McMillan. 2017. "Introduction: Researching Immigrant and Emigrant Voting." Political Science 69 (2): 93-100. doi.org/10.1080/00323187.2017.1334510.

Bauböck, R. 2003. “Towards a Political Theory of Migrant Transnationalism.” International Migration Review 37 (3): 700-723. doi.org/10.1111/j.1747-7379.2003.tb00155.x.

Bauböck, R. 2006. "Introduction." In Migration and Citizenship: Legal Status, Rights and Political Participation, edited by R. Bauböck, 9-13. Amsterdam University Press.

Beckman, L. 2006. “Citizenship and Voting Rights: Should Resident Aliens Vote?” Citizenship Studies 10 (2): 153-165. doi.org/10.1080/13621020600633093. 
Beckman, L. 2008. "Who Should Vote? Conceptualizing Universal Suffrage in Studies of Democracy." Democratization 15 (1): 29-48. doi.org/10.1080/13510340701768091.

Belton, K. 2019. "Muddy Waters: Citizenship and the Right to Vote in the Commonwealth Caribbean Migratory Context." Commonwealth \& Comparative Politics, published online January 22. doi.org/10.1080/14662043.2019.1545526.

Bender, G. J. 1967. "Political Socialization and Political Change." The Western Political Quarterly 20 (2): 390-407.

Berrens, R. P., A. K. Bohara, H. Jenkins-Smith, C. Silva, and D. L. Weimer. 2003. "The Advent of Internet Surveys for Political Research: A Comparison of Telephone and Internet Samples.” Political Analysis 11 (1): 1-22. doi.org/10.1093/pan/11.1.1.

Boccagni, P., and J. Ramírez. 2013. "Building Democracy or Reproducing 'Ecuadoreanness'? A Transnational Exploration of Ecuadorean Migrants' External Voting." Journal of Latin American Studies 45 (4): 721-750. doi.org/10.1017/S0022216X13001181.

Brand, L. A. 2006. Citizens Abroad: Emigration and the State in the Middle East and North Africa. Cambridge University Press.

Caramani, D., and F. Grotz. 2015. "Beyond Citizenship and Residence? Exploring the Extension of Voting Rights in the Age of Globalization." Democratization 22 (5): 799-819. doi.org/10.1080/13510347.2014.981668.

CASEN (Caracterización Socioeconómica Nacional). 2015. "Archivo histórico de Encuesta CASEN" [Historical Archive of the CASEN Survey]. Ministerio de Desarrollo Social, Observatorio Social, Chile. $\quad$ http://observatorio.ministeriodesarrollosocial.gob.cl/casenmultidimensional/casen/casen 2015.php.

Chaudhary, A. R. 2018. "Voting Here and There: Political Integration and Transnational Political Engagement among Immigrants in Europe." Global Networks 18 (3): 437-460. doi.org/10.1111/glob.12171.

Dahl, R. A. 1971. Polyarchy: Participation and Opposition. New Haven, CT: Yale University Press.

DEM (Departamento de Extranjería y Migración). 2015. “Anuario Estadístico Nacional 2015” [National Statistical Yearbook]. www.extranjeria.gob.cl/estadisticas-migratorias/.

Doña Reveco, C., and P. Sotomayor. 2017. “¿Por qué votan los inmigrantes? Participación electoral e integración entre migrantes en Chile" [Why do immigrants vote? Electoral participation and integration among migrants in Chile]. Observatorio de Desigualdades, December 20. 
Victoria Finn

Pre-Print of Migrant Voting in Citizenship Studies

observatoriodesigualdades.icso.cl/2017/12/por-que-votan-los-inmigrantes-participacionelectoral-e-integracion-entre-migrantes-en-chile/.

Earnest, D. C. 2015. "The Enfranchisement of Resident Aliens: Variations and Explanations." Democratization 22 (5): 861-883. doi.org/10.1080/13510347.2014.979162.

Echeverría, G. 2015. Access to Electoral Rights Chile. EUDO Citizenship Observatory, RSCAS/EUDOCIT-ER 2015/20. Badia Fiesolana, San Domenico di Fiesole, Italy: Robert Schuman Centre for Advanced Studies.

Erdal, M. B., and C. Oeppen. 2013. "Migrant Balancing Acts: Understanding the Interactions Between Integration and Transnationalism." Journal of Ethnic and Migration Studies 39 (6): 867-884. doi.org/10.1080/1369183X.2013.765647.

Escobar, C. 2015. "Immigrant Enfranchisement in Latin America: From Strongmen to Universal Citizenship.” Democratization 22 (5): 927-950. doi.org/10.1080/13510347.2014.979322.

Ferris, D., R. Hayduk, A. Richards, E. Strauss Schubert, and M. Acri. (2019). "Noncitizen Voting Rights in the Global Era: A Literature Review and Analysis." Journal of International Migration and Integration 1-23. doi.org/10.1007/s12134-019-00687-8.

Finn, V., and S. Umpierrez de Reguero. (2020). "Inclusive Language for Exclusive Policies: A Case of Restrictive Migration Governance." Latin American Policy.

Fox, J. 2005. "Unpacking 'Transnational Citizenship'.” Annual Review of Political Science 8: 171-201. doi.org/10.1146/annurev.polisci.7.012003.104851.

Gamlen, A. 2015. "The Impacts of Extra-Territorial Voting: Swings, Interregnums and Feedback Effects in New Zealand Elections from 1914 to 2011.” Political Geography 44: 1-8. doi.org/10.1016/j.polgeo.2014.08.005.

Glick Schiller, N., L. Basch, and C. Szanton Blanc. 1992. “Transnationalism: A New Analytic Framework for Understanding Migration." Annals of the New York Academy of Sciences 645 (1): 1-24. doi.org/10.1111/j.1749-6632.1992.tb33484.x.

GLOBALCIT (Global Citizenship Observatory) “Electoral Law Indicators.” Accessed February 25, 2019. globalcit.eu/citizenship-indicators/?topic=AM votlawcitres.

Guarnizo, L. E., A. R. Chaudhary, and N. N. Sørensen. 2017. "Migrants' Transnational Political Engagement in Spain and Italy." Migration Studies mnx061: 1-42. doi.org/10.1093/migration/mnx061. 
Guarnizo, L. E., A. Portes, and W. Haller. 2003. "Assimilation and Transnationalism: Determinants of Transnational Political Action among Contemporary Migrants.” American Journal of Sociology 108 (6): 1211-1248. doi.org/10.1086/375195.

Herrera, M. and P. Navia. Unpublished manuscript. "The Effect of Enfranchised Migrants on Electoral Turnout. Evidence from Chile in 2012."

Hyman, H. H. 1959. Political Socialization: A Study in the Psychology of Political Behavior. New York: Free Press.

IDEA (Institute for Democracy and Electoral Assistance). 2019. Data \& Tools. Retrieved from: www.idea.int

INE (Instituto Nacional de Estadísticas) 2017. National Institute of Statistics, Chile. www.ine.cl/.

Joppke, C. 2007. "Transformation of Citizenship: Status, Rights, Identity." Citizenship Studies 11 (1): 37-48. doi.org/10.1080/13621020601099831.

Kashiwazaki, C. 2013. "Incorporating Immigrants as Foreigners: Multicultural Politics in Japan." Citizenship Studies 17 (1): 31-47. doi.org/10.1080/13621025.2013.764216.

Margheritis, A. 2015. Access to Electoral Rights Uruguay. EUDO Citizenship Observatory, RSCAS/EUDO-CIT-ER 2015/7. Badia Fiesolana, San Domenico di Fiesole, Italy: Robert Schuman Centre for Advanced Studies.

Marshall, T. H. 1964. Class, Citizenship and Social Development. New York.

McMillan, K. 2015. "National Voting Rights for Permanent Residents: New Zealand's Experience.” In Global Migration: Old Assumptions, New Dynamics, edited by D. Acosta Arcarazo and A. Wiesbrock, 101-128. Santa Barbara: Praeger.

Mosler, H. B., and L. Pedroza. 2016. “An Unexpected Pioneer in Asia: The Enfranchisement of Foreign Residents in South Korea." Ethnopolitics 15 (2): 187-210. doi.org/10.1080/17449057.2014.954318.

Niemi, R. G., and M. A. Hepburn. 1995. “The Rebirth of Political Socialization.” Perspectives on Political Science 24 (1): 7-16. doi.org/10.1080/10457097.1995.9941860.

Østergaard-Nielsen, E. 2003. “The Politics of Migrants' Transnational Political Practices.” International Migration Review 37 (3): 760-786. doi.org/10.1111/j.1747-7379.2003.tb00157.x.

Palop-García, P., and L. Pedroza. 2018. "Passed, Regulated, or Applied? The Different Stages of Emigrant Enfranchisement in Latin America and the Caribbean." Democratization 26 (3): 401421. doi.org/10.1080/13510347.2018.1534827. 
Paul, R. 2013. "Space, the Final Frontier of Political Socialisation Research: Geopolitical contexts, migrant resocialisation and political remittances." In Growing into Politics: Contexts and timing of political socialisation, edited by S. Abendschön, 183-216. ECPR Press.

Pedroza, L. 2019. Citizenship Beyond Nationality: Immigrants' Right to Vote Across the World. University of Pennsylvania Press.

Pedroza, L., and P. Palop-García. 2017. "The Grey Area between Nationality and Citizenship: An Analysis of External Citizenship Policies in Latin America and the Caribbean." Citizenship Studies 21 (5): 587-605. doi.org/10.1080/13621025.2017.1316701.

Pedroza, L., P. Palop-García, and B. Hoffmann. 2016. Emigrant Policies in Latin America and the Caribbean. Santiago de Chile: FLASCO Chile.

Peltoniemi, J. (2018). Transnational political engagement and emigrant voting. Journal of Contemporary European Studies, 26(4), 392-410. doi.org/10.1080/14782804.2018.1515727.

Peters, F., H. Schmeets, and M. Vink. (2019). Naturalisation and Immigrant Earnings: Why and to Whom Citizenship Matters. European Journal of Population. doi.org/10.1007/s10680-019-095401.

Ramírez, J., and S. Umpierrez de Reguero. 2019. "Estado, (e)migración y voto: análisis longitudinal de la experiencia ecuatoriana (2006-2019).” ODISEA. Revista de Estudios Migratorios 6: 31-64.

SERVEL (Servicio Electoral de Chile). 2017. "Más de 260 mil extranjeros están habilitados para votar en Chile" [More than 260,000 Foreigners Are Able to Vote in Chile]. September 27, 2017. www.servel.cl/mas-de-260-mil-extranjeros-estan-habilitados-para-votar-en-chile/.

Tonkiss, K., and T. Bloom. 2015. "Theorising Noncitizenship: Concepts, Debates and Challenges." Citizenship Studies 19 (8): 837-852.

Tsuda, T. 2012. "Whatever Happened to Simultaneity? Transnational Migration Theory and Dual Engagement in Sending and Receiving Countries." Journal of Ethnic and Migration Studies 38 (4): 631-649. doi.org/10.1080/1369183X.2012.659126.

UN DESA (United Nations, Department of Economic and Social Affairs) 2017. "International Migration Report 2017: Highlights.” www.un.org/development/desa/publications/international-migration-report-2017.html.

Waldinger, R. 2008. “Between 'Here' and 'There': Immigrant Cross-Border Activities and Loyalties.” International Migration Review 42 (1): 3-29. doi.org/10.1111/j.1747-7379.2007.00112.x. 
Victoria Finn

Pre-Print of Migrant Voting in Citizenship Studies

Waldinger, R. 2015. The Cross-Border Connection: Immigrants, Emigrants, and Their Homelands. Cambridge: Harvard University Press.

Wasburn, P. C., and T. J. Adkins Covert. 2017. Making Citizens: Political Socialization Research and Beyond. Springer.

White, S., N. Nevitte, A.Blais, E. Gidengil, and P. Fournier. 2008. "The Political Resocialization of Immigrants: Resistance or Lifelong Learning?" Political Research Quarterly 61 (2): 268-281. doi.org/10.1177/1065912908314713.

\section{Appendix}

Table A1 Characteristics of the Sample, $N=680$

\begin{tabular}{|c|c|c|c|}
\hline Variable & Response & $\begin{array}{l}\text { Number of } \\
\text { Respondents }\end{array}$ & $\begin{array}{l}\text { Percentage of } \\
\text { Respondents }\end{array}$ \\
\hline \multirow{3}{*}{$\begin{array}{l}\text { Knowledge of voting rights in } \\
\text { the destination country }\end{array}$} & Yes & 387 & $56.9 \%$ \\
\hline & No & 183 & $26.9 \%$ \\
\hline & I don't know & 110 & $16.2 \%$ \\
\hline \multirow{3}{*}{ Interest in politics } & Uninterested & 72 & $10.6 \%$ \\
\hline & $\begin{array}{l}\text { Somewhat } \\
\text { interested }\end{array}$ & 264 & $38.8 \%$ \\
\hline & Very interested & 344 & $50.6 \%$ \\
\hline \multirow{4}{*}{ Intention to stay } & $0-5$ years & 53 & $7.8 \%$ \\
\hline & $6-10$ years & 81 & $11.9 \%$ \\
\hline & I don't know & 216 & $31.8 \%$ \\
\hline & Forever & 330 & $48.5 \%$ \\
\hline \multirow{2}{*}{ Linguistic communication } & High & 423 & $62.2 \%$ \\
\hline & Low & 257 & $37.8 \%$ \\
\hline \multirow{5}{*}{ Age } & $16-24$ & 34 & $5.0 \%$ \\
\hline & $25-33$ & 121 & $17.8 \%$ \\
\hline & $34-42$ & 222 & $32.6 \%$ \\
\hline & $43-50$ & 141 & $20.7 \%$ \\
\hline & $>50$ & 162 & $23.8 \%$ \\
\hline \multirow{3}{*}{ Tenure in destination country } & $6-10$ years & 308 & $45.3 \%$ \\
\hline & $11-20$ years & 272 & $40.0 \%$ \\
\hline & $>20$ years & 94 & $13.8 \%$ \\
\hline \multirow{3}{*}{ Education } & High school or less & 221 & $32.5 \%$ \\
\hline & $\begin{array}{l}\text { Professional } \\
\text { training }\end{array}$ & 229 & $33.7 \%$ \\
\hline & University & 230 & $33.8 \%$ \\
\hline \multirow{2}{*}{ Sex } & Woman & 423 & $62.8 \%$ \\
\hline & Man & 251 & $37.2 \%$ \\
\hline
\end{tabular}


Victoria Finn

Pre-Print of Migrant Voting in Citizenship Studies

\begin{tabular}{|c|c|c|c|}
\hline \multirow{2}{*}{$\begin{array}{l}\text { Origin country borders Chile } \\
\text { (Argentina, Bolivia, Peru) }\end{array}$} & Yes & 302 & $44.4 \%$ \\
\hline & No & 378 & $55.6 \%$ \\
\hline \multirow{2}{*}{$\begin{array}{l}\text { Origin country is in Latin } \\
\text { America or the Caribbean } \\
\text { (non-border country) }\end{array}$} & Yes & 631 & $92.8 \%$ \\
\hline & No & 49 & $7.2 \%$ \\
\hline \multirow{2}{*}{ Elections } & First round & 347 & $51.0 \%$ \\
\hline & Second round & 333 & $49.0 \%$ \\
\hline
\end{tabular}

Source: Frequencies of select responses from the author's survey, Chile 2017.

Table A2 Multinomial Logistic Regression Results by Migrant Voting Types, N=680

\begin{tabular}{|c|c|c|c|c|}
\hline Variable & Response & $\begin{array}{c}\text { Immigrant } \\
\text { Voting }\end{array}$ & $\begin{array}{c}\text { Emigrant } \\
\text { Voting }\end{array}$ & $\begin{array}{c}\text { Dual } \\
\text { Transnation } \\
\text { al Voting }\end{array}$ \\
\hline \multirow{3}{*}{$\begin{array}{l}\text { Knowledge of voting } \\
\text { rights in the destination } \\
\text { country }\end{array}$} & Yes & . & . & . \\
\hline & No & $\begin{array}{l}-22.340 \\
(0.000)\end{array}$ & $\begin{array}{l}0.662^{*} \\
(0.317)\end{array}$ & $\begin{array}{l}-4.565^{* * *} \\
(0.674) \\
\end{array}$ \\
\hline & I don't know & $\begin{array}{l}-3.032^{* *} \\
(1.072)\end{array}$ & $\begin{array}{l}0.259 \\
(0.320)\end{array}$ & $\begin{array}{l}-4.369 * * * \\
(0.794)\end{array}$ \\
\hline \multirow{3}{*}{ Interest in politics } & Uninterested & 2 & . & . \\
\hline & $\begin{array}{l}\text { Somewhat } \\
\text { interested }\end{array}$ & $\begin{array}{l}0.718 \\
(0.881)\end{array}$ & $\begin{array}{c}-0.088 \\
(0.377)\end{array}$ & $\begin{array}{l}0.835 \\
(0.536)\end{array}$ \\
\hline & Very interested & $\begin{array}{l}1.274 \\
(0.894)\end{array}$ & $\begin{array}{l}0.450 \\
(0.399)\end{array}$ & $\begin{array}{l}2.047^{* * *} \\
(0.552)\end{array}$ \\
\hline \multirow{4}{*}{ Intention to stay } & $0-5$ years & $\begin{array}{l}-1.605 \\
(1.182) \\
\end{array}$ & $\begin{array}{l}-0.197 \\
(0.471) \\
\end{array}$ & $\begin{array}{l}0.000^{* * *} \\
(0.582)\end{array}$ \\
\hline & $6-10$ years & $\begin{array}{l}-0.570 \\
(0.750)\end{array}$ & $\begin{array}{l}-0.349 \\
(0.377)\end{array}$ & $\begin{array}{l}-0.381 \\
(0.490)\end{array}$ \\
\hline & I don't know & $\begin{array}{l}-0.446 \\
(0.523)\end{array}$ & $\begin{array}{l}0.035 \\
(0.289)\end{array}$ & $\begin{array}{l}0.019 \\
(0.348)\end{array}$ \\
\hline & Forever & . & . & . \\
\hline \multirow[b]{2}{*}{ Linguistic communication } & High & . & . & . \\
\hline & Low & $\begin{array}{l}0.250 \\
(0.491)\end{array}$ & $\begin{array}{l}0.418 \\
(0.268)\end{array}$ & $\begin{array}{l}0.691^{*} \\
(0.323)\end{array}$ \\
\hline \multirow{6}{*}{ Age } & $16-24$ & $\begin{array}{l}-1.249 \\
(1.232)\end{array}$ & $\begin{array}{l}-1.882^{* * *} \\
(0.521)\end{array}$ & $\begin{array}{l}-2.757 * * \\
(0.802)\end{array}$ \\
\hline & $25-33$ & $\begin{array}{l}-0.025 \\
(0.745)\end{array}$ & $\begin{array}{l}-0.294 \\
(0.412) \\
\end{array}$ & $\begin{array}{l}-1.076 \\
(0.515) \\
\end{array}$ \\
\hline & $34-42$ & $\begin{array}{l}-0.080 \\
(0.621)\end{array}$ & $\begin{array}{l}-0.049 \\
(0.364)\end{array}$ & $\begin{array}{l}-0.498 \\
(0.424)\end{array}$ \\
\hline & $43-50$ & . & . & . \\
\hline & $>50$ & $\begin{array}{l}-0.550 \\
(0.705)\end{array}$ & $\begin{array}{l}-0.010 \\
(0.408)\end{array}$ & $\begin{array}{l}-0.162 \\
(0.474)\end{array}$ \\
\hline & $6-10$ years & . & . & . \\
\hline
\end{tabular}


Victoria Finn

Pre-Print of Migrant Voting in Citizenship Studies

\begin{tabular}{|c|c|c|c|c|}
\hline \multirow{2}{*}{$\begin{array}{l}\text { Tenure in destination } \\
\text { country }\end{array}$} & $11-20$ years & $\begin{array}{l}0.396 \\
(0.536)\end{array}$ & $\begin{array}{l}-0.672^{*} \\
(0.288)\end{array}$ & $\begin{array}{l}0.098 \\
(0.348)\end{array}$ \\
\hline & $>20$ years & $\begin{array}{l}0.793 \\
(0.754) \\
\end{array}$ & $\begin{array}{l}-0.766 \\
(0.451)\end{array}$ & $\begin{array}{l}0.378 \\
(0.529)\end{array}$ \\
\hline \multirow{3}{*}{ Education } & High school or less & $\begin{array}{l}-0.0872 \\
(0.598)\end{array}$ & $\begin{array}{l}0.069 \\
(0.320)\end{array}$ & $\begin{array}{l}-0.011 \\
(0.383)\end{array}$ \\
\hline & $\begin{array}{l}\text { Professional } \\
\text { training } \\
\end{array}$ & $\begin{array}{l}-0.128 \\
(0.524) \\
\end{array}$ & $\begin{array}{l}0.085 \\
(0.318) \\
\end{array}$ & $\begin{array}{l}0.358 \\
(0.373) \\
\end{array}$ \\
\hline & University & . & . & . \\
\hline \multirow[b]{2}{*}{ Sex } & Woman & . & . & . \\
\hline & Man & $\begin{array}{l}0.436 \\
(0.473) \\
\end{array}$ & $\begin{array}{l}0.136 \\
(0.264) \\
\end{array}$ & $\begin{array}{l}0.030 * \\
(0.324) \\
\end{array}$ \\
\hline \multirow{2}{*}{$\begin{array}{l}\text { Origin country borders } \\
\text { Chile }\end{array}$} & Yes & . & . & $\cdot$ \\
\hline & No & $\begin{array}{l}-0.611 \\
(0.517) \\
\end{array}$ & $\begin{array}{l}-0.626^{*} \\
(0.281) \\
\end{array}$ & $\begin{array}{l}-1.275^{* * *} \\
(0.345)\end{array}$ \\
\hline \multirow{2}{*}{$\begin{array}{l}\text { Origin country is in Latin } \\
\text { America or the Caribbean } \\
\text { (non-border country) }\end{array}$} & Yes & . & . & . \\
\hline & No & $\begin{array}{l}1.414 \\
(0.799)\end{array}$ & $\begin{array}{l}0.442 \\
(0.512)\end{array}$ & $\begin{array}{l}0.367 \\
(0.660)\end{array}$ \\
\hline \multirow[b]{2}{*}{ Elections } & First round & $x^{2}=7$ & . & . \\
\hline & Second round & $\begin{array}{l}0.402 \\
(0.477)\end{array}$ & $\begin{array}{l}-0.039 \\
(0.287)\end{array}$ & $\begin{array}{l}1.055^{* *} \\
(0.334)\end{array}$ \\
\hline \multicolumn{2}{|l|}{ Intercept } & $\begin{array}{l}-0.774 \\
(1.216) \\
\end{array}$ & $\begin{array}{l}1.570^{* *} \\
(0.598)\end{array}$ & $\begin{array}{l}0.611 \\
(0.750)\end{array}$ \\
\hline & Chi-square & \multicolumn{3}{|l|}{$3195^{* * *}$} \\
\hline & Cox and Snell Test & \multicolumn{3}{|l|}{0.485} \\
\hline & \begin{tabular}{|l|} 
Nagelkerke Test \\
\end{tabular} & \multicolumn{3}{|l|}{0.541} \\
\hline & McFadden Test & \multicolumn{3}{|l|}{0.293} \\
\hline & $N$ & \multicolumn{3}{|l|}{680} \\
\hline
\end{tabular}

Source: From the author's survey, Chile 2017.

Notes: Significance level: $*<0.05, * *<0.01, * * *<0.001$. Standard errors are in parentheses.

Abstention is the reference category for migrant voting; all other reference categories for answers are marked with a period (.). Given the non-probabilistic sample, the results hold only for this group of respondents. 